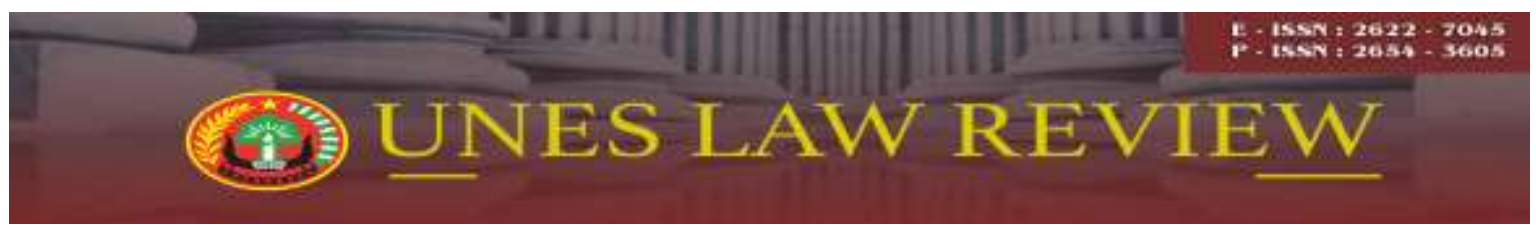

Email: uneslawreview@gmail.com

Online: http://review-unes.com/index.php/law

Volume 2, Issue 1, September 2019

\title{
UPAYA NON PENAL PENINGKATAN KESADARAN HUKUM MASYARAKAT UNTUK MENGGUNAKAN HELM BERSTANDAR NASIONAL INDONESIA DI POLRES TANAH DATAR
}

Fitri Dewi Utami

Program Magister Ilmu Hukum, Universitas Ekasakti, Padang

E-mail : fitridewiutami@gmail.com

\begin{abstract}
Article 106 paragraph (8) of Law Number 22 Year 2009 concerning Road Traffic and Transportation states that every person driving a Motorcycle and Motorcycle Passenger must use a helmet that meets Indonesian national standards. The level of legal awareness of two-wheeled riders in the jurisdiction of Tanah Datar police station to use SNI-standard helmets is still low. It can be seen from the increase in traffic violations that do not use helmets in Tanah Datar Regency in the last 2 (two) years from 2017 to 2018. Efforts of Non Penal Satlantas of Tanah Datar Regional Police in Increasing Legal Awareness of Two-Wheeled Riders to Use SNI-Standard Helmets is to continue disseminating information to road users, Extension to the bykers / motorbike clubs about the traffic order carried out in front of Pagaruyung palace. Training on the obligation to use SNI helmets for all motorcycle drivers in Tanah Datar. Patrol is one of the police activities carried out by 2 or more members of the National Police.
\end{abstract}

Kata Kunci: Helm, Lalulintas, Kesadaran hukum, upaya non penal

\section{PENDAHULUAN}

Lalu lintas dan angkutan jalan mempunyai peran strategis dalam mendukung pembangunan dan integrasi nasional sebagai bagian dari upaya memajukan kesejahteraan umum sebagaimana diamanatkan oleh Undang-Undang Dasar Negara Republik Indonesia Tahun 1945. Lalu-lintas dan angkutan jalan sebagai bagian dari sistem transportasi nasional harus dikembangkan potensi dan perannya untuk mewujudkan keamanan, keselamatan, ketertiban, dan kelancaran berlalu lintas dan angkutan jalan dalam rangka mendukung pembangunan ekonomi dan pengembangan wilayah. Pasal 1 ayat (1) Undangundang Nomor 22 Tahun 2009 tentang Lalu Lintas Angkutan Jalan menyebutkan "Lalu lintas dan Angkutan Jalan adalah suatu kesatuan sistem yang terdiri atas Lalu Lintas, Angkutan Jalan, Jaringan Lalu Lintas dan Angkutan Jalan, Prasarana Lalu Lintas dan Angkutan Jalan, Kendaraan, Pengemudi, Pengguna Jalan, serta pengelolaannya.” 
Ketertiban lalu lintas pengguna jalan sangat bergantung pada tingkat kesadaran masyarakat. Apalagi ketertiban lalu lintas berkolerasi pada keamanan kolektif yang berhubungan dengan keselamatan pengguna jalan itu sendiri. Dalam Pasal 31 ayat (1) Undang Undang Nomor 22 Tahun 2009 Tentang Lalu Lintas dan Angkutan Jalan menyebutkan bahwa "Ketertiban Lalu Lintas dan Angkutan Jalan adalah suatu keadaan berlalu lintas yang berlangsung secara teratur sesuai dengan hak dan kewajiban setiap Pengguna Jalan" Standar ini jelas menggantungkan keamanan dan keselamatan pengguna jalan pada pengguna jalan itu sendiri sebagai bagian tak terpisahkan dari tujuan menciptakan keselamatan berlalu lintas.

Salah satu hal menyangkut dengan keselamatan pengguna jalan adalah penggunaan helm, sebagaimana diatur dalam Pasal 106 ayat (8) Undang-Undang Nomor 22 Tahun 2009 Tentang Lalu Lintas dan Angkutan Jalan menyebutkan bahwa setiap orang yang mengemudikan Sepeda Motor dan Penumpang Sepeda Motor wajib menggunakan helm yang memenuhi standar nasional Indonesia.

Kecelakaan lalu lintas yang melibatkan sepeda motor dapat mengakibatkan pengemudi atau penumpangnya mengalami luka parah bahkan sampai meninggal dunia. Hal ini salah satunya disebabkan karena minimnya perlindungan pada pengemudi sepeda motor, bila dibandingkan dengan mobil, sepeda motor tidak memiliki instrumen peredam, sabuk keselamatan (safety belt) dan kantong udara (air bag) guna menahan benturan. Memang sepeda motor memiliki keunggulan ukuran yang lebih kecil dibandingkan mobil. Hal ini membuat pengendara lebih mudah untuk melaju dan bergerak di keramaian lalu lintas. Namun hal ini jugalah yang kemudian dapat membuat mereka lebih mudah terlibat dalam kecelakaan dan biasanya pengemudi sepeda motor mengalami luka serius (Poppi Anugrah wati 2010).

Tingginya angka kecelakaan yang melibatkan sepeda motor ini diiringi juga dengan fakta hasil penelitian di Indonesia, bahwa satu dari tiga orang yang mengalami kecelakaan sepeda motor mengalami cedera di kepala. Dampak lebih lanjut dari cedera di kepala dapat menyebabkan gangguan pada otak, pusat sistem syaraf, dan urat syaraf tulang belakang bagian atas.

Penggunaan helm merupakan syarat penting bagi pengemudi sepeda motor untuk menjamin keselamatan dan keamanan organ vital manusia yaitu otak. Penggunaan helm 
juga tidak boleh sembarangan yaitu helm yang telah memenuhi Standar Nasional Indonesia (SNI). Penggunaan helm ditingkat pengemudi sepeda motor dewasa ini sangat minim. Hal ini berarti, bahwa tingkat kesadaran masyarakat pengemudi sepeda motor sangat rendah. Dalam mengemudikan sepeda motor, masyarakat lebih cenderung tidak mempedulikan keselamatan diri sendiri. Pengemudi sepeda motor tidak mempedulikan pentingnya penggunaan helm untuk bagian vital dari manusia yaitu otak. Hal tersebut dapat dilihat dari banyaknya pengemudi sepeda motor yang tidak menggunakan helm berstandar SNI. Dalam aktifitas sehari hari bisa dilihat kurangnya tingkat kesadaran pengguna jalan atau pengemudi kendaraan bermotor dalam menggunakan helm.

Pelayanan kepada masayarakat dibidang lalu lintas dilaksanakan juga untuk meningkatkan kualitas hidup masyarakat yang modern lalu lintas merupakan faktor utama pendukung produktifitasnya (Muhammad Ihsan 2019). Pelanggaran lalu lintas tidak menggunakan helm SNI menduduki angka yang tinggi di wilayah hukum Polres Tanah Datar. Berbagai kesulitan ditemui dalam hal penertibannya oleh petugas Satlantas. Kecenderungan masyarakat hanya mengunakan helm saat berkendaraan tanpa mempeduli standar dari helm yang digunakan. Perlu berbagai upaya terutama melalui kebijakan sosial untuk meningkatkan kesadaran hukum masyarakat agar mengunakan helm SNI.

Berdasarkan latar belakang pemikiran yang telah dipaparkan di atas, maka rumusanpermasalahan adalah tingkat kesadaran hukum pengendara roda dua dan upaya non penal oleh Satlantas Polres Tanah Datar dalam meningkatkan kesadaran hukum pengendara roda dua untuk mengunakan helm berstandar SNI di wilayah hukum Satlantas Polres Tanah Datar.

\section{METODE PENELITIAN}

Spesifikasi penelitian adalah deskriptif analisis, dengan metode pendekatan yuridis normatif dan pendekatan yuridis empiris. Jenis data yang digunakan adalah data sekunder dan data primer. Data sekunder diperoleh dari studi dokumen dan data primer diperoleh dari lapangan. Teknik pengumpulan data pada data sekunder dilakukan dengan studi kepustakaan dan pada data primer dengan wawancara dan observasi. Data yang diperoleh kemudian dianalisa secara kualitatif serta disajikan dengan deskriptif analitis. 


\section{PEMBAHASAN}

\section{Tingkat Kesadaran Hukum Pengendara Roda Dua Di Wilayah Hukum Polres Tanah Datar Untuk Mengunakan Helm Berstandar SNI}

Kabupaten Tanah Datar memiliki penduduk kurang lebih sebanyak 348.555 jiwa dengan semakin berkembangnya ilmu pengetahuan dan pemikiran manusia yang modren maka kebutuhan akan teknologi semakin tinggi, seiring berjalannya waktu lama kelamaan kendaraan bertambah di kabupaten ini karena kebutuhan masyarakatnya dan oleh sebab itu tuntutan akan memiliki kendaraan juga semakin banyak, melihat padatnya jalan raya oleh populasi kendaraan maka bisa dipastikan juga banyak sekali Polantas yang siap siaga di setiap titik tertentu untuk menjalankan tugas dan fungsinya sebagai aparat keamanan di jalan raya. Dan tercatat sebanyak 4373 pada tahun 2017 dan 5749 kendaraan roda dua yang masih aktif membayar pajak kendaraan di kabupaten Tanah Datar.

Semakin banyaknya angka dan populasi kendaraan di kabupaten Tanah Datar dianggap masyarakat mengetahui dan menyadari berbagai aturan lalu lintas. Terutama tentang kewajiban untuk mengunakan helm Ber-Standar Nasional. Pelanggaran tidak menggunakan helm ber-SNI menjadi angka pelanggaran lalu lintas tertinggi diantara bentuk pelanggaran lalulintas di Kabupaten Tanah Datar. Tingginya angka pelanggaran lalulintas tidak menggunakan helm ber-SNI menunjukan masih rendahnya kesadaran hukum masyarakat dalam menggunakan helm ber-SNI.

Tingginya angka kecelakaan bagi pengendara sepeda motor, banyak yang mengalami kecelakaan cedera di kepala. Penyebabnya bisa dipastikan, karena tidak memakai helm sehingga tidak ada yang melindungi kepalanya ketika terbentur, kecelakaan yang mengakibatkan meninggal dunia itu terjadi pengendara jatuh sendiri dan kepalanya terbentur keras dan tabrakan dengan kendaraan lain. Padahal jika saja mereka menggunakan helm, mengkin nyawa mereka masih bisa diselamatkan. Helm memang tidak dapat dipandang remeh oleh pengendara sepeda motor karena helm sangat bermanfaat untuk keselamatan pengendara.

Jika dilihat dari pelanggaran lalu lintas yang tidak menggunakan helm terjadi di Kabupaten Tanah Datar dalam kurun waktu 2 (dua) tahun terakhir sejak tahun 2017 sampai dengan 2018 masih terlihat tinggi. Dari data yang ditampilkan di atas dapat dilakukan analisa data pengendara yang tidak memakai helm ada peningkatan seperti pada tahun 
2017 yang tidak menggunakan helm sebanyak 856 dan sebanyak 1826 pada tahun 2018 terjadi peningkatan sebanyak 970 kasus yang tidak menggunakan helm. Peningkatan angka pelanggaran lalulintas tidak menggunakan helm ber-SNI menunjukan kurangnya kesadaran hukum masyarakat terhadap kewajiban penggunaan helm ber-SNI. Terhadap kasus seperti ini diperlukan langkah-langkah konkrit untuk mencarikan jalan keluarnya dalam upaya .

Berdasarkan kusioner yang disebarkan, dapat dikemukakan tingkat pengetahuan masyarakat/pengendara tentang kewajiban penggunaan helm ber-SNI yakni dari 100 orang responden pengendara roda dua hanya 67 orang dari masyarakat/pengendara telah mengetahui tentang kewajiban menggunakan helm ber-SNI. Bila dipersentasekan berarti 67\%. Dapat di ambil kesimpulan bahwa masih banyak masyarakat yang belum mengetahui Peraturan Lalu lintas dapat dipahami jika jumlah kendaraan roda dua di wilayah Kepolisian Resort Tanah Datar yang mencapai angka 4373 pada tahun 2017 dan 5749 kendaraan roda dua pada tahun 2018 .

Bila masyarakat memakai helm saat terjadi kecelakaan sepeda motor maka kepala pengendara akan terhindar dari benturan langsung, disanalah salah satu hakikat dari pentingnya kesadaran masyarakat dalam pemakaian helm. Disamping ketaatan masyarakat dalam pemakaian helm saat mengendara juga yang sangat penting untuk dipatuhi sebagaimana yang atur dalam Peraturan Perundang-undangan Lalulintas adalah jenis Standar helm yang digunakan yaitu helm yang Standart Nasional Indonesia ( SNI ).

Kesadaran hukum berarti suatu proses penilaian terhadap hukum yang berlaku atau hukum yang dikehendaki.Setiap masyarakat pada umumnya memiliki kesadaran hukum yang tinggi, namun masyarakat pada umumnya cenderung menaati peraturan yang ada disebabkan oleh adanya sanksi yang ada di dalam suatu peraturan perundang-undangan, bukan karena adanya kesadaran dari dalam diri masyarakat tersebut.

\section{Upaya Non Penal Satlantas Polres Tanah Datar Dalam Meningkatkan Kesadaran Hukum Pengendara Roda Dua Untuk Mengunakan Helm Berstandar SNI}

Kebijakan non penal yaitu kebijakan di luar hukum pidana yang bertujuan mengurangi angka kecelakaan lalu lintas yaitu meliputi teguran simpatik, adanya pembinaan, penyuluhan kepada masyarakat (kampanye keselamatan berkendara, debat 
publik, kunjungan, seminar dan diskusi), program kegiatan "Gerakan Disiplin Berlalu Lintas" dan operasi khusus kepolisian. Sedangkan secara edukatif seperti polisi sahabat anak, patroli keamanan sekolah dilakukan pelajar, pelatihan safety riding, dan tegasnya tindakan penegakan hukum polisi untuk edukasi terwujudnya kepastian hukum.

Dalam meningkatkan kesadaran hukum berlalu lintas, Polres Tanah Datar melakukan tindakan-tindakan preventif dengan mengajak seluruh masyarakat yang berada di daerah Tanah Datar dengan memberikan penyuluhan-penyuluhan tentang Lalu lintas kesekolah-sekolah, SD, SMP, SMA dengan tujuan untuk dapat menanamkan sejak dini disiplin berlalu lintas dan memberitahu apa yang diperbolehkan atau yang tidak diperbolehkan dalam mengendarai sepeda motor. Kebanyakan pelajar mengendarai sepeda motor ugal-ugalan, tidak memakai helm dan tidak mementingkan bahaya keselamatan yang dapat mengakibatkan kecelakaan lalu lintas.

Satuan Lalu Lintas Polres Tanah Datar juga melakukan razia rutin dengan cara patroli untuk meningkatkan kesadaran masyrakat dalam menggunakan helm. Kebanyakan masyarakat memakai helm ketika ada polisi yang patroli atau melewati pos polisi.Ini juga menjadi kebiasaan banyak orang. Kebanyakan dari pengendara sepeda motor memakai helm hanya karena takut ditilang, padahal helm merupakan salah satu kelengkapan dalam berkendara yang berfungsi untuk melindungi kepala sipengendara sepeda motor apabila terjadi kecelakaan.

Mengingat semakin mulusnya jalan-jalan di daerah ini, dengan sendirinya akan menimbulkan suatu permasalahan terutama dibidang lalu lintas, karena dengan semakin ramai lalu lintas akan semakin banyak pula pelanggaran dan kecelakaan lalu lintas yang terjadi. Dengan semakin ramainya lalu lintas di daerah ini, maka tidak dapat dipungkiri bahwa hal tersebut akan menimbulkan dampak negatif, terutama mengenai pelanggaran dan kecelakaan lalu lintas bagi pemakai jalan raya.

Untuk meminimalisir dampak kecelakaan sepeda motor (terutama pada bagian kepala korban), menggunakan helm yang memenuhi Standar Nasional Indonesia saat berkendara merupakan hal yang sangat wajib dan perlu mendapatkan perhatian khusus. Kecelakaan lalu lintas karena tidak memakai helm dapat menimbulkan cidera dikepala dan luka parah. Kebanyakan dari pelanggar yang tidak menggunakan helm yaitu pelajar mereka merasa helm itu dipkai kalau ada polisi saja, dan sering terjadi kejar-kejaran antara 
pihak kepolisian dengan pelajar karena tidak memakai helm sehingga polisi kesulitan untuk menangkap pelajar tersebut.

Berbagai cara dilakukan oleh polisi lalu lintas untuk menegakkan kedisiplinan salah satunya adalah melakukan patroli dijalan raya dan menepati pos-pos polisi di setiap kawasan tertentu, tentunya ini merupakan suatu dari pihak kepolisian lalu lintas guna menertibkan para pengguna jalan sehingga para pengendara tidak semena-mena serta lebih bisa meningkatkan kedisiplinan dijalan raya. Di kawasan Polres Tanah Datar terdapat beberapa pos polisi yaitu sekitar empat pos polisi. Razia adalah pemeriksaan surat-surat kendaraan dan juga kelengkapan pengendara saat mengendarai motor guna menertibkan masyarakat. Apakah polisi sering melakukan razia atau tidakrazia sangat berguna untuk mengontorol dan meningkatkan ketertiban masyarakat sebagai pengendara kendaraan bermotor di jalan raya, dan razia ini sering dilakukan di sekitaran jalan raya di Kabupaten Tanah Datar.

Upaya penanggulangan yang ditempuh oleh Sat lantas Polres Tanah Datar terhadap pengendara sepeda motor tidak menggunkan helm ber-SNI, adalah upaya non penal secara preventif (pencegahan). Hal ini dimaksudkan sebagai usaha mengadakan perubahanperubahan yang bersifat positif terhadap kemungkinan terjadinya gangguan dalam ketertiban dan keamanan (stabilitas hukum). Tindakan preventif ini merupakan usaha yang lebih baik dari pada membasmi setelah terjadinya suatu tindak pidana. Mencegah adalah adalah lebih baik dari pada mencoba mendidik penjahat menjadi orang baik. Lebih baik disini berarti lebih mudah mencapai tujuan yang diinginkan, bahkan menjadi salah satu ajaran penting dalam kriminologi yaitu usaha-usaha untuk mencegah kejahatan harus lebih di utamakan dari pada usaha-usaha untuk memperbaiki para pelaku.

Kebijakan non penal yaitu kebijakan di luar hukum pidana yang bertujuan mengurangi angka kecelakaan lalu lintas yaitu meliputi teguran simpatik, adanya pembinaan, penyuluhan kepada masyarakat (kampanye keselamatan berkendara, debat publik, kunjungan, seminar dan diskusi).

Upaya program yang sudah diberikan kepada masyarakat seperti sosialisasi masyarakat yang ingin membuat SIM, membagi brosur tentang kepatuhan terhadap lalu lintas dan akibat melanggar lalu lintas juga penerangan tentang UU No 22 Tahun 2009 kepada sasarannya masyarakat dan pelajar. Polantas berperan melayani masyarakat 
terhadap kelancaran berlalu lintas di jalan dan memberi pertolongan saat terjadi laka lantas di jalan serta sebaiknya dibiasakan pendidikan disiplin berlalu lintas dikenalkan lebih dini kepada anak-anak.

\section{Kendala Dalam Upaya Non Penal Oleh Satlantas Polres Tanah Datar Dalam Meningkatkan Kesadaran Hukum Pengendara Roda Dua Untuk Mengunakan Helm Berstandar SNI}

Sat Lantas Polres Tanah Datar, sudah memberikan program sosialisasi, penyuluhan memberi penjelasan dan pembinaan kepada masyarakat tentang pelaksanaan dan tujuan dibentuk UU No 22 Tahun 2009. Tetapi masalah utama adalah pengguna jalan yang sengaja melanggar disebabkan karena kurangnya kesadaran hukum dari masyarakat itu sendiri. Peran polisi sudah mengayomi masyarakat tetapi tergantung pandangan masyarakat bagaimana menilainya, tidak semua polisi buruk seperti yang dianggap masyarakat selama ini. Misalnya menerima suap, uang damai dan sebagainya, walaupun itu hanya salah satu dibanding seribu tetapi penilaian negatif masyarakat menjadi buruk kepada semua polisi.

Seorang penegak hukum seperti polisi lalu lintas misalnya, harus sadar bahwa dia merupakan pejabat resmi yang berperan sebagai pihak yang melayani kepentingan masyarakat, oleh karena itu setiap penegak hukum di jalan raya harus menolak segala jenis pemberian hadiah yang cenderung mempengaruhi sifat keputusannya. Karena kepolisian Negara Republik Indonesia memiliki tugas membina masyarakat untuk meningkatkan partisipasi masyarakat, kesadaran hukum masyarakat serta ketaatan warga masyarakat terhadap hukum dan peraturan perundang-undangan.

Kendala yang Dihadapi Oleh Polisi Dalam Menegakkan Hukum Berlalu Lintas terutama kesadaran untuk menggunakan helm ber SNI adalah:

1) Kurangnya kesadaran hukum pada masyarakat

Kesadaran hukum masyarakat tidak tumbuh dengan sendirinya, meskipun dalam diri setiap anggota masyarakat mempunyai kecenderungan untuk hidup yang teratur. Untuk itu kesadaran hukum masyarakat perlu dipupuk dan dikembangkan. Melalui pola pembinaan yang efektif dan intensif. Apabila penegak hukum dianggap sebagai orang yang paling mengetahui akan suatu aturan, dengan demikian apa yang dilakukan aparat penegak hukum, maka akan menjadi teladan bagi masyarakat. Sebagai contoh, aparat 
penegak hukum yang melakukan tindakan-tindakan tidak terpuji di jalanan, maka hal tersebut secara tidak langsung memberikan contoh yang tidak baik kepada masyarakat khsusunya pengguna jalan.Kurangnya kesadaran hukum pada masyarakat.

Kaitannya dengan efektifitas penerapan/penegakan hukum, masalah kesadaran hukum masyarakat memegang peranan yang sangat penting. Masyarakat yang ingin melihat terciptanya suatu ketertiban dalam masyarakat akan berusaha untuk teratur sehingga tercipta suatu pola hubungan tingkah laku masyarakat menurut suatu pola tertentu.

Kesadaran hukum masyarakat baru akan tercipta apabila di dukung oleh segenap elemen masyarakat, dapat dikemukakan di sini bahwa semakin besar kesadaran hukum masyarakat maupun aparat, maka akan semakin kecil kemungkinan masyarakat untuk bertingkah laku yang tidak sesuai dengan hukum.

2) Kurangnya kemampuan dari Polisi

Sebagaimana yang diharapkan, baik secara kualitas (penguasaan teknis dan taktis berlalu lintas) maupun kuantitas (ratio ketersediaan aparat lalulintas dengan kasus pelanggaran dan penertiban yang ditangani serta penyebaran jumlah petugas lalulintas). Kelemahan sumber daya manusia dapat pula muncul dari aspek cultural yaitu sikapsikap aparatpetugas lalulintas yang arogan, tidak memiliki sifat melayani, manipulatif, diskriminatif dan sebagainya. Apabila penegak hukum dianggap sebagai orang yang paling mengetahui akan suatu aturan, dengan demikian apa yang dilakukan aparat penegak hukum, maka akan menjadi teladan bagi masyarakat. Sebagai contoh, aparat penegak hukum yang melakukan tindakan-tindakan tidak terpuji di jalanan, maka hal tersebut secara tidak langsung memberikan contoh yang tidak baik kepada masyarakat khsusunya pengguna jalan.

3) Kurangnya sarana prasarana yang mendukung.

Banyaknya sarana lalu lintas yang terpasang dijalan seperti rambu rambu yang rusak sehingga tidak terlihat maka dapat mengganggu kelancaran lalu lintas, menimbulkan banyak masyarakat melakukan pelanggaran dan tidak ada yang mau mengalah. Rambu, plang dan aturan lalu lintas yang dibuat oleh polisi tidak sesuai isi UU No. 2 tahun 2002. Terbatasnya prasarana seperti kurangnya pengadaan pos polisi termasuk adanya penjaga dalam pos tersebut kadang dibiarkan kosong tidak terpakai. 
Pendanaan yang diberikan pemerintah tidak diwujudkan oleh yang berwenang untuk membuat sarana dan prasarana lalu lintas yang lengkap supaya masyarakat dapat nyaman di jalan raya.

\section{PENUTUP}

Tingkat Kesadaran Hukum Pengendara Roda Dua Di Wilayah Hukum Polres Tanah Datar Untuk Mengunakan Helm Berstandar SNI masih rendah hal ini terlihat dari pelanggaran lalu lintas yang tidak menggunakan helm terjadi di Kabupaten Tanah Datar dalam kurun waktu 2 (dua) tahun terakhir sejak tahun 2017 sampai dengan 2018 masih terlihat tinggi. Upaya Non Penal Satlantas Polres Tanah Datar Dalam Meningkatkan Kesadaran Hukum Pengendara Roda Dua Untuk Mengunakan Helm Berstandar SNI adalah terus melakukan sosialisasi bagi pengguna jalan, dengan memberikan sosialisisasi bagaimana mereka tertib memakai helm dalam berkendara, serta mengetahui manfaat helm tersebut.

\section{DAFTAR PUSTAKA}

\section{Buku Teks:}

Poppi Anugrah wati, Pengaruh iklan Helm SNI Terhadap Tingkat Kesadaran Penggunaan Helm SNI Pada Pelajar Kelas XII Jurusan Akuntansi SMK Konsai Pekan Baru: Skripsi, UIN SUSKA, Riau, 2010

Muhammad Ihsan, Lalu Lintas Dan Permasalahannya, Pasca Sarjana UGM Yogyakarta. Univ Gadjah Mada. Yogyakarta, 2009

\section{Peraturan Undang-Undang:}

Undang-undang Nomor 22 Tahun 2009 Tentang Lalu Lintas dan Angkutan Jalan.

Undang-undang UU No. 2 tahun 2002 tentang Kepolisian Republik Indonesia. 